\title{
Individual particle analysis of aerosols collected under haze and non-haze conditions at a high-elevation mountain site in the North China plain
}

\author{
W. J. Li ${ }^{1,2,3}$, D. Z. Zhang ${ }^{4}$, L. Y. Shao ${ }^{2}$, S. Z. Zhou ${ }^{1}$, and W. X. Wang ${ }^{1}$ \\ ${ }^{1}$ Environment Research Institute, Shandong University, Jinan, Shandong 250100, China \\ ${ }^{2}$ State Key Laboratory of Coal Resources and Safe Mining, China University of Mining and Technology, \\ Beijing 100083, China \\ ${ }^{3}$ State Key of Laboratory of Atmospheric Boundary Physics and Atmospheric Chemistry, Institute of Atmospheric Physics, \\ Chinese Academy of Sciences, Beijing 100029, China \\ ${ }^{4}$ Faculty of Environmental and Symbiotic Sciences, Prefectural University of Kumamoto, Kumamoto 862-8502, Japan
}

Received: 10 July 2011 - Published in Atmos. Chem. Phys. Discuss.: 8 August 2011

Revised: 8 November 2011 - Accepted: 8 November 2011 - Published: 24 November 2011

\begin{abstract}
The North China plain is a region with megacities and huge populations. Aerosols over the highly polluted area have a significant impact on the regional and global climate. In order to investigate the physical and chemical characteristics of aerosol particles in elevated layers there, observations were carried out at the summit of Mt. Tai (1534 m a.s.1.) from 19 to 28 April, 2010, when the air masses were advected from the east (phase-I: 19-21 April), from the south (phaseII: 22-25 April), and from the northwest (phase-III: 2628 April). Individual aerosol particles were identified with transmission electron microscopy (TEM), new particle formation (NPF) and growth events were monitored by a widerange particle spectrometer, and ion concentrations in $\mathrm{PM}_{2.5}$ were analyzed. During phase-I and phase-II, haze layers caused by anthropogenic pollution were observed, and a high percentage of particles were sulfur-rich (47-49\%). In phaseIII, the haze disappeared due to the intrusion of cold air from the northwest, and mineral dust particles from deserts were dominant $(43 \%)$. NPF followed by particle growth during daytime was more pronounced on hazy than on clear days. Particle growth during daytime resulted in an increase of particle geometric mean diameter from $10-22 \mathrm{~nm}$ in the morning to $56-96 \mathrm{~nm}$ in the evening. TEM analysis suggests that sulfuric acid and secondary organic compounds should be important factors for particle nucleation and growth. However, the presence of fine anthropogenic particles (e.g., soot, metal, and fly ash) embedded within S-rich particles indicates that
\end{abstract}

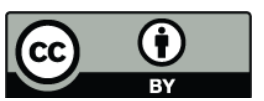

Correspondence to: W. J. Li

(liweijun@sdu.edu.cn) they could weaken NPF and enhance particle growth through condensation and coagulation. Abundant mineral particles in phase-III likely suppressed the NPF processes because they supplied sufficient area on which acidic gases or acids condensed.

\section{Introduction}

Atmospheric particles in the troposphere, especially submicron particles that have relatively long atmospheric residence times, can change the earth's radiative balance through scattering and absorbing radiation (Charlson et al., 1992; IPCC, 2007). Long-term records of surface radiation measurements can be interpreted as a dichotomous pattern of a widespread decrease in surface solar radiation ("global dimming"), with a partial recovery more recently at many locations ("brightening") (Wild, 2009). Anthropogenic and natural perturbations of the radiation balance depend either directly or indirectly on several inherent properties of particles, including mass concentration, composition, and size distribution. In particular, the chemical composition of aerosols among various size ranges is a key factor in determining their hygroscopicity, ability of activation, and optical properties (Andreae and Rosenfeld, 2008; Hudson, 2007; Lohmann and Feichter, 2005).

In the past two decades, rapidly industrializing East China has contributed massive quantities of anthropogenic pollutants into the troposphere because of inadequate pollution controls fostered by weak regulations (Fang et al., 2009; He et al., 2002; Lu et al., 2010). Observations have revealed

Published by Copernicus Publications on behalf of the European Geosciences Union. 
that anthropogenic aerosol particles from the North China plain (NCP) are transported long distances into remote areas (Jacob et al., 2003; Jaffe et al., 1999; Kahn et al., 2004). One complication of this transport, however, is that aerosols and aerosol-cloud interactions may differ depending on the region, its local pollutant concentrations, and the height above the ground surface (Rosenfeld, 2000; Wild, 2009). In situ measurements of air pollutants are usually carried out at ground level, but these ground-based results cannot completely represent the physical and chemical properties of aerosol particles at upper levels or in the free troposphere (Pratt and Prather, 2010). Compared to aerosol particles at ground level, those at upper levels are more easily transported long distances because of the higher wind velocity of a more uniform direction or they may directly act as cloud condensation nuclei (CCN). Examining the physics and chemistry of these aerosol particles around the top of the planetary boundary layer (PBL) above the highly polluted $\mathrm{NCP}$ is a prerequisite to answer what types of aerosols can be mostly transported into the free troposphere. In addition, the mixing state of aerosol particles at upper levels is significant for understanding their effects on cloud condensation processes and regional climate (Lee et al., 2002; Lohmann and Feichter, 2005; Bond et al., 2006; Knopf et al., 2010; Li et al., 2011). However, such knowledge about the upper atmosphere of the PBL and the free troposphere over the NCP has yet to be obtained, although a few studies recently investigated various anthropogenic gases and particulate concentrations at Mt. Tai (Fu et al., 2010; Ren et al., 2009; Wang et al., 2011; Yamaji et al., 2010).

Individual particle analysis by transmission electron microscopy (TEM) has become a reliable technique to characterize aerosol particles (Adachi and Buseck, 2008; Chen et al., 2006; Geng et al., 2010; Giere et al., 2006; Li and Shao, 2009b; Matsuki et al., 2010; Niemi et al., 2006). Because of its resolution down to fractions of a nanometer, TEM can provide detailed information on the size, composition, morphology, structure, and mixing state of individual aerosol particles. Such information at ground level has already been obtained in the polluted NCP (Li et al., 2010; Zhang et al., 2000). This kind of detailed examination of the sizedependent chemical and physical properties and the mixing state of aerosols at upper levels is critically needed for the further development and evaluation of cloud and global climate models (Fuzzi et al., 2006; Pratt and Prather, 2010; Knopf et al., 2010).

The objective of this study was to characterize in detail individual aerosol particles collected in the atmospheric boundary layer at the summit of Mt. Tai, the highest mountain in the NCP, including the relative abundance of various particle types, mixing states, sources, and new particle formation (NPF) and growth. During the sampling conducted 19-29 April 2010, three periods of distinctly different wind directions were encountered and were classified as "phase-I" from the east, "phase-II" from the south, and "phase-III"

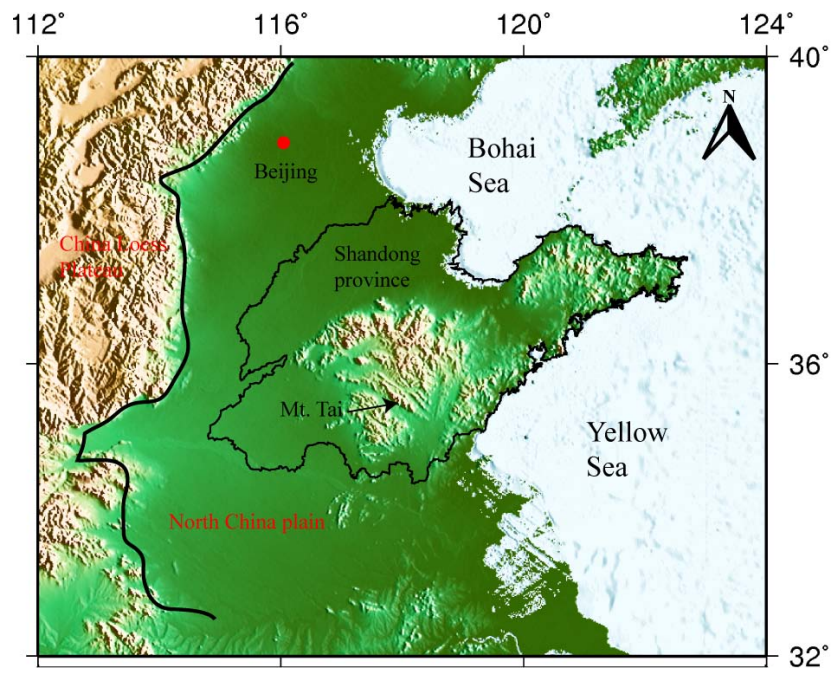

Fig. 1. Map showing Mt. Tai located in Shandong Province in the North China Plain.

from the northwest. We identified and compared the chemical and physical properties of the aerosol particles in these three different phases.

\section{Experiment}

\subsection{Sampling site}

Observations were carried out at the summit of Mt. Tai $\left(36.251^{\circ} \mathrm{N}, 117.101^{\circ} \mathrm{E}, 1534 \mathrm{~m}\right.$ a.s.1.). The mountain, isolated within the NCP, is located in Shandong province, overlooking the city of Tai' an (population: 500000 ), $15 \mathrm{~km}$ to the south (Fig. 1). The city of Ji'nan (capital of Shandong province, population: 2.1 million) is $60 \mathrm{~km}$ to the north. Mt. Tai is the highest mountain near the East China Sea on the transport path of the Asian continental outflow and faces towards the Korean peninsula and Japanese Islands. Moreover, because its elevation of $1500 \mathrm{~m}$ places it close to the top of the PBL, it serves as a site suitable for investigating aerosol particles in the PBL over the highly polluted NCP.

\subsection{Aerosol sampling and analysis}

Aerosol particles were collected on copper TEM grids coated with carbon film (carbon type-B, 300-mesh copper, Tianld Co., China) by a single-stage cascade impactor with a 0.5 $\mathrm{mm}$-diameter jet nozzle and an air flow rate of $0.51 \mathrm{~min}^{-1}$. For these conditions, the calculated effective size $d_{50}$ is about $0.5 \mu \mathrm{m}$ (Marple et al., 1993). Sampling times varied from 2 to $5 \mathrm{~min}$, depending on the particle loading as estimated from visibility. Three or four samples were collected in the morning (07:00-09:00 local time (LT)), midday (11:00-14:00 LT), and late afternoon (15:00-18:00 LT) each day, with a total of 30 samples collected. During the sampling period, rainfall 


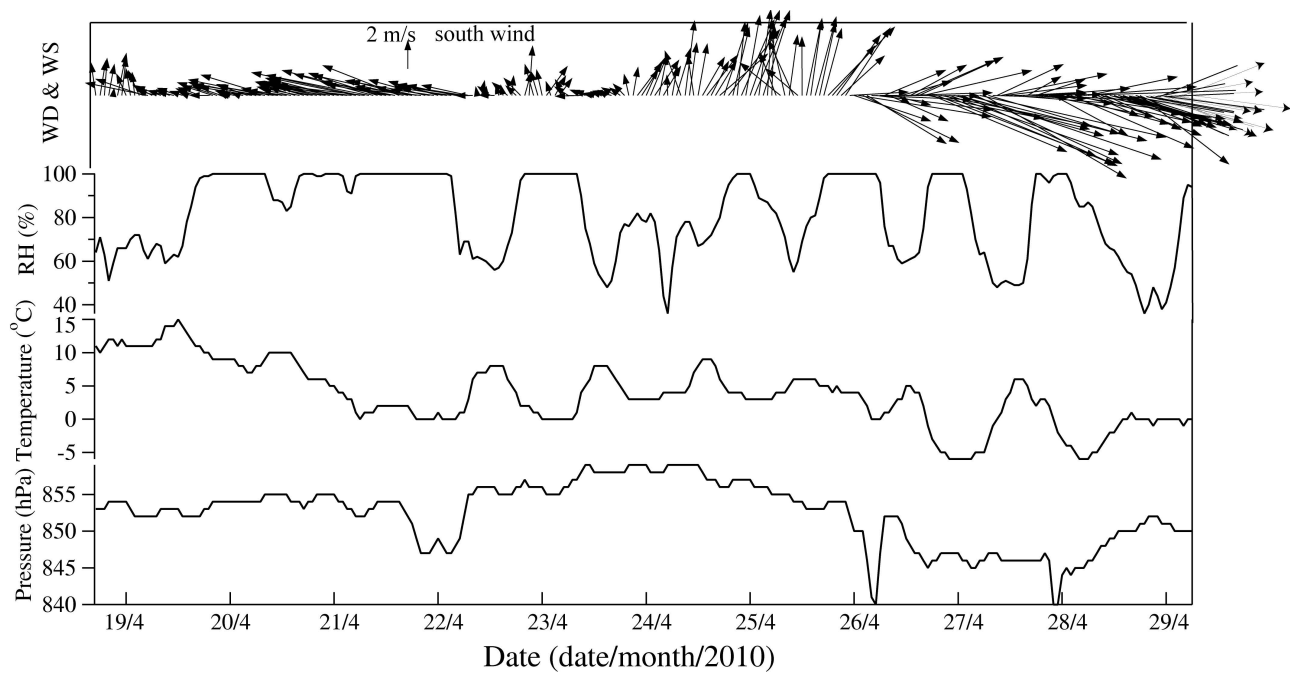

Fig. 2. Continual variations of wind speed (WS), wind direction (WD), relative humidity (RH), temperature, and pressure monitored at the summit of Mt. Tai during 19-29 April, 2010.

occurred once (in the daytime of 21 April), and snowfall occurred once (around 20:00-22:00 LT on 26 April). After sample collection, we used optical microscopy with magnification from $\times 500$ to $\times 1200$ to check whether the carbon film and aerosol distribution on the TEM grids were suitable for analysis. Then, the grid was placed in a sealed, dry plastic tube and stored in a desiccator at $25^{\circ} \mathrm{C}$ and $20 \pm 3 \% \mathrm{RH}$ to minimize exposure to ambient air and preserve it for analysis.

Aerosol particles on the TEM grids were analyzed with a JEM-2100 TEM operated at $200 \mathrm{kV}$. Particles examined by TEM were dry at the time of observation in the vacuum of the electron microscope. The effects of water, semi-volatile organics, and $\mathrm{NH}_{4} \mathrm{NO}_{3}$ could not be considered. Elemental composition was determined semi-quantitatively by an energy-dispersive X-ray spectrometer (EDS) that can detect elements heavier than carbon. EDS spectra were collected for only $15 \mathrm{~s}$ to minimize radiation exposure and potential beam damage. Copper could not be analyzed because of interferences from the copper TEM grid. In this study, TEM images with low-magnification between $\times 2000$ and $\times 5000$ were quickly obtained from the center to periphery of each sample so that the aerosol distribution and morphology were generally known by the skilled operator. To understand the morphology, composition, size, and mixing state of each aerosol particle, high-resolution TEM images were taken and EDS was used to determine the composition of their component parts such as coatings, inclusions, and aggregations. An ellipse was fitted over a particle outline, with the arithmetic mean of its short and long axes determining the particle diameter in two dimensions.

A MiniVol sampler (Airmetrics, USA) with a constant pumping rate of $51 \mathrm{~min}^{-1}$ was employed to collect $\mathrm{PM}_{2.5}$ on quartz-fiber filters for the analysis of soluble inorganics.
Due to technical problems and meteorological conditions, we only collected seven samples (Table S1). Five cations $\left(\mathrm{Na}^{+}\right.$, $\mathrm{K}^{+}, \mathrm{NH}_{4}^{+}, \mathrm{Ca}^{2+}$, and $\left.\mathrm{Mg}^{2+}\right)$ and five anions $\left(\mathrm{F}^{-}, \mathrm{Cl}^{-}, \mathrm{NO}_{2}^{-}\right.$, $\mathrm{NO}_{3}^{-}$, and $\mathrm{SO}_{4}^{2-}$ ) were quantified by ion chromatography (IC).

In addition, measurements of wind speed, wind direction, relative humidity $(\mathrm{RH})$, barometric pressure, and ambient temperature were automatically recorded every $10 \mathrm{~min}$ by a Kestral 4500 Pocket Weather Tracker (Nielsen-Kellermann Inc., USA) (Fig. 2).

\subsection{Particle number measurement}

A wide-range particle spectrometer (WPS ${ }^{\mathrm{TM}}$, MSP corporation model 1000XP) continuously measured number and size distributions of the ambient aerosol particles. This instrument is a high-resolution aerosol spectrometer which combines the principles of differential mobility analysis (DMA), condensation particle counting (CPC), and laser light scattering (LPS). Although this instrument has a range of $10 \mathrm{~nm}$ to $10 \mu \mathrm{m}$, we set the upper limit to $1 \mu \mathrm{m}$ because of low collection efficiency of larger particles. It should be noted that the measured particle diameters determined by WPS using the laser sensor differ from the diameters derived by TEM because of their different measurement principles.

\section{Results}

\subsection{General description of meteorological conditions}

Meteorological conditions have a dominant influence on aerosol particle concentrations. In particular, wind direction and wind speed appear to be the most important factors in the formation of different pollution episodes such 


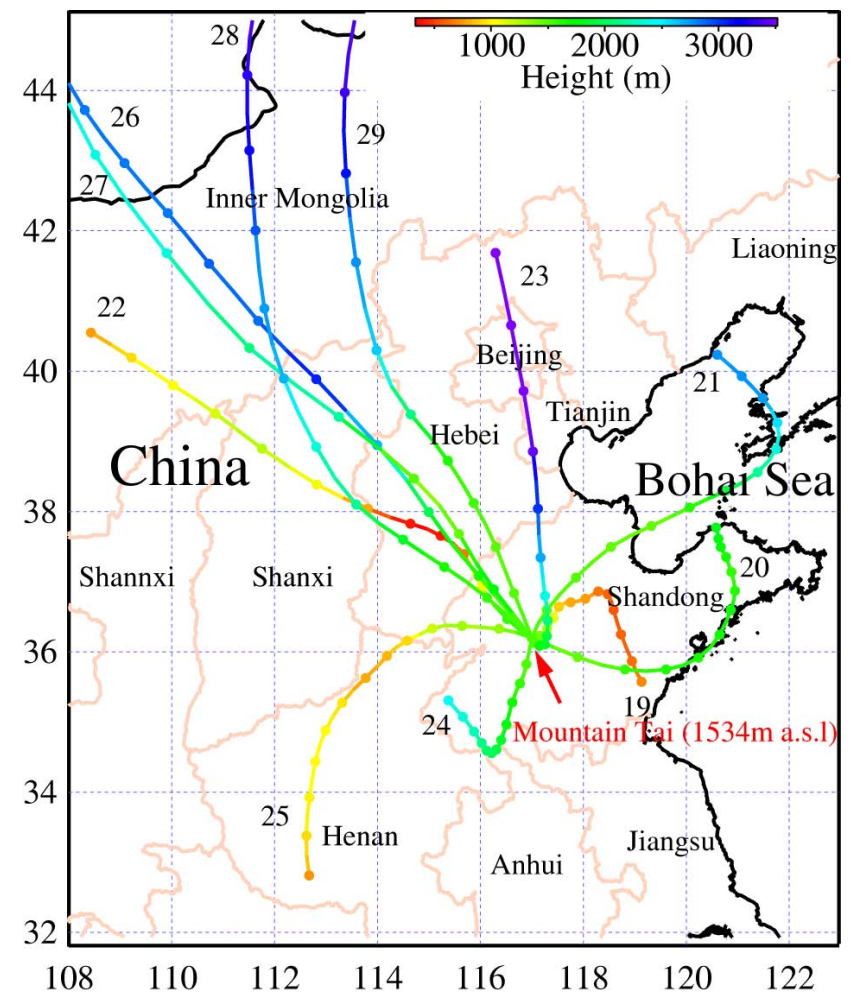

Fig. 3. 24-h air mass back trajectories arriving at 24:00 (local time) to the summit of Mt. Tai (1540 ma.s.l) from 19 to 29 April 2010. Date number is marked on each trajectory, and solid dots on each line represent 2-h intervals (http://ready.arl.noaa.gov/ HYSPLIT.php).

as Asian dust storms or the severe brown hazes in northern China. With regard to the wind directions on Mt. Tai, we found three different scenarios: in the first phase on 1921 April, 2010 (phase-I), prevailing winds were from the northeast to east; in the second one on 22-25 April (phaseII), they were from the southwest to south; and in the third one on 26-28 April (phase-III), they were from the northwest (Fig. 2). RH on Mt. Tai typically reached saturation $(100 \%)$ after 18:00 LT, because a mass of low-level, nonprecipitating clouds formed following the daily temperature decrease after sunset in spring (Li et al., 2011).

Back-trajectory analyses indicate that the air masses in phase-I came from eastern Shandong peninsula and they brought ground-level air pollutants to the summit of Mt. Tai (Fig. 3). Except on 23 April in phase-II, air mass back trajectories from Shanxi, Hebei, Henan, and western Shandong province brought ground-level air pollutants to the mountain. Back trajectory analysis for the 23 rd of April shows that an air mass from the free troposphere above northern Hebei province moved south to Tai' an in $20 \mathrm{~h}$, and then returned to Mt. Tai in $4 \mathrm{~h}$. In phase-III all the air masses began in Inner Mongolia, were transported in the free troposphere, and then descended to Mt. Tai. A strong dust storm was observed about 17:10-17:40 LT on 26 April following the passage of a cold front. At the same time the temperature dropped to $-5^{\circ} \mathrm{C}$.

The Chinese Meteorological Administration (CMA) defines clear and hazy days as follows: "clear": visibility $\geq 10 \mathrm{~km}$ and "hazy": visibility $<10 \mathrm{~km}$ and $\mathrm{RH} \leq 80 \%$. Haze layers with visibility $<5 \mathrm{~km}$ were observed in phase-I (except 21 April) and phase-II, but haze was not observed after 26 April. Wind directions in Fig. 2 were in good agreement with the 24-h air mass back trajectories in Fig. 3, suggesting that the conditions on the summit of Mt. Tai adequately represent the results of the important air pollution advective patterns on the regional scale of the PBL.

\subsection{Major individual aerosol particles and their sources}

The composition and morphology of 717 aerosol particles were classified into six groups: sulfur (S)-rich (internally mixed with organic matter (OM) and soot), fly ash, metal, crustal mineral, Ca-S/N, and Na/K-S/N (Fig. 4). For the classification of particles, we firstly considered high peaks in the EDS spectra of individual particles. The EDS data of particle were statistically analyzed and it was found that, except carbon and oxygen, the average content of $\mathrm{S}$ in $249 \mathrm{~S}$-rich particles was $74 \%$ and that of $\mathrm{Na} / \mathrm{K}$ in $48 \mathrm{Na} / \mathrm{K}-\mathrm{S} / \mathrm{N}$ particles was $71 \%$ by weight. Therefore, we used a threshold $70 \%$ by weight to identify the particle types. In addition, morphologies of individual particles were also considered to identify some particle types. For example, some fly ash and crustal mineral particles both contain $70 \%$ of Si by weight but they display different morphologies as described below.

$\mathrm{S}$-rich particles contain $\mathrm{O}$ and $\mathrm{S}$ with minor $\mathrm{K}$ and $\mathrm{Na}$, and they are extremely beam sensitive. EDS spectra of S-rich particles are classified into two types: "particle a" consists of a mixture of ammonium sulfate and minor other sulfates (e.g., $\mathrm{K}_{2} \mathrm{SO}_{4}$ and $\mathrm{Na}_{2} \mathrm{SO}_{4}$ ), and "particle b" represents ammonium sulfate (Fig. 4a). The former is the most abundant inorganic aerosol in this study, as was also observed in urban and biomass-burning particles sampled in different areas (Adachi and Buseck, 2008; Li et al., 2010; Murphy et al., 2006; Posfai et al., 2003). The S-rich particles in TEM images can display a rounded shape. Most of them are internally mixed with OMs, and many also include soot, fly ash, crustal mineral, and metal particles. OMs acting as particle coatings do not exhibit any well-defined shape and are difficult to directly identify through particle morphology (Li and Shao, 2009b). We noticed that externally mixed soot and spherical organic particles were hardly ever observed in the upper-level hazes, which is different from ground-based observations in hazes ( $\mathrm{Li}$ and Shao, 2009b; Li et al., 2010). In this study, we do not separate soot and OM particles from each S-rich particle.

Spherical fly ash particles contain O, Si, and Al with minor $\mathrm{Ca}, \mathrm{Ti}, \mathrm{Mn}$, and Fe, as shown in Fig. 4b. Most of these particles contain $\mathrm{O}, \mathrm{Si}$ and $\mathrm{Al}$ (particle a), or $\mathrm{O}$ and $\mathrm{Si}$ (particle b). 


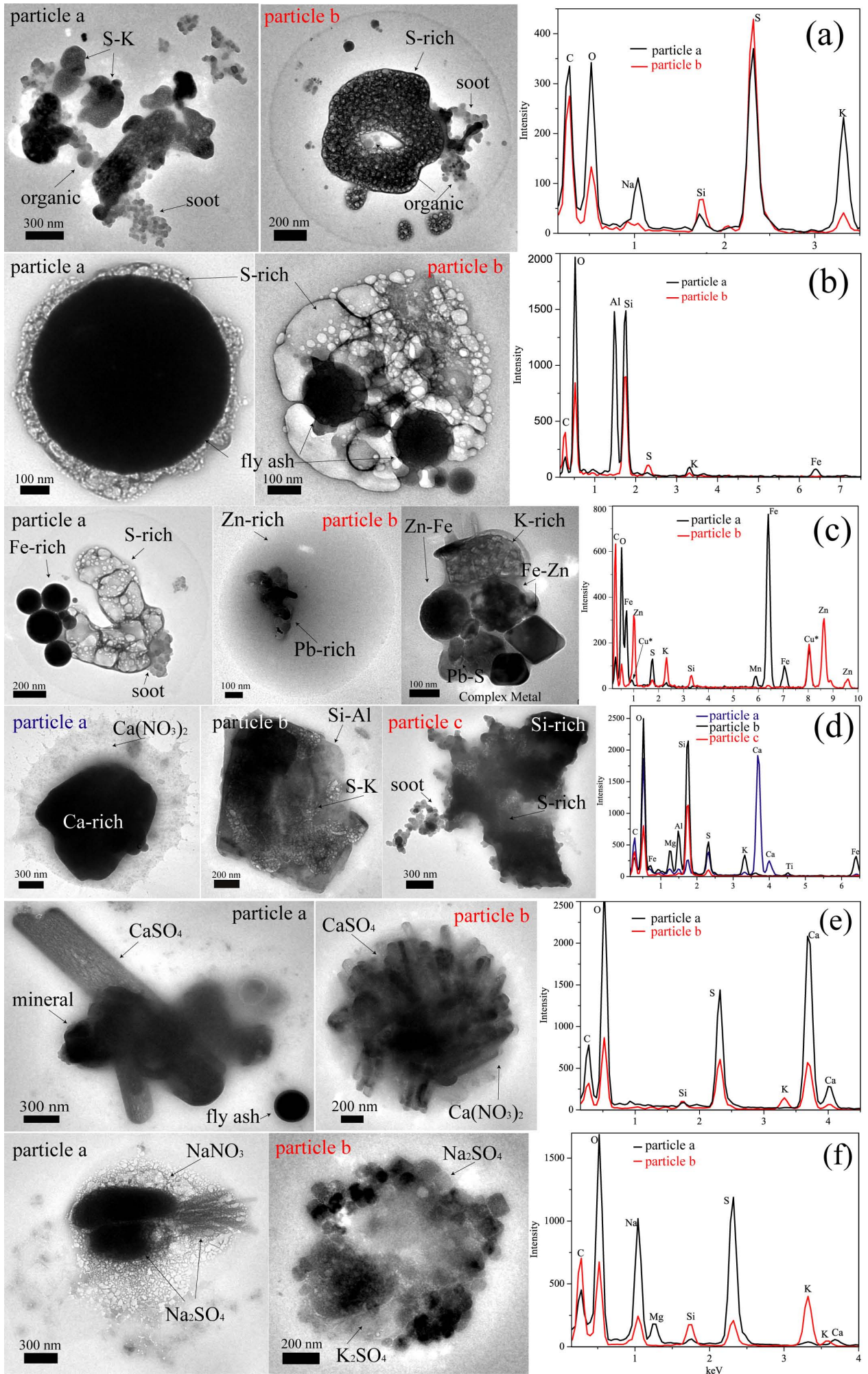

Fig. 4. TEM images of different individual aerosol particles and their corresponding EDS spectra. (a) S-rich particles (particle a-b) mainly contain S with a certain amount of K, Na. Most S-rich particles contain organic matter and soot. (b) Fly ash particles (particle a-b) contain $\mathrm{Si}$ and/or $\mathrm{Al}$ with minor Fe, Mn, and Ti. (c) Metal particles (particle a-b) are Fe-rich, $\mathrm{Zn}-\mathrm{Pb}$, Zn-Fe, or their mixtures. (d) Crustal mineral particles (particle a-c) have complex compositions, which depend on mineral types. (e) $\mathrm{Ca}-\mathrm{S} / \mathrm{N}_{\text {particles }}\left(\right.$ particle a-b) are $\mathrm{CaSO} \mathrm{S}_{4}, \mathrm{Ca}\left(\mathrm{NO}_{3}\right)_{2}$, or their mixtures. (f) $\mathrm{Na} / \mathrm{K}-\mathrm{S} / \mathrm{N}$ particles (particle a-b) mostly are $\mathrm{NaNO}_{3}, \mathrm{Na}_{2} \mathrm{SO}_{4}, \mathrm{KNO}_{3}, \mathrm{~K}_{2} \mathrm{SO}_{4}$, or their mixtures. 
Such small refractory particles (diameter $<1 \mu \mathrm{m}$ ) are mostly mixed within secondary sulfate particles through coagulation. They are typical components of the anthropogenic aerosols from all sources of coal combustion, whether it is due to household heating/cooking, power plants, or industrial activities (Li and Shao, 2009b).

Metal particles include Fe-rich particles with lesser amounts of $\mathrm{Zn}$-rich, $\mathrm{Zn}-\mathrm{Pb}$, and $\mathrm{Pb}$-rich particles. An individual Fe-rich particle is a small aggregation of several spherical Fe-rich particles (Fig. 4c, particle a). Spherical Fe-rich particles look the same as fly ash in TEM images, despite their totally different composition. Based on their morphology and composition, Fe-rich particles were probably emitted by steel industries. Moreover, rounded $\mathrm{Zn}$-rich and $\mathrm{Zn}-\mathrm{Pb}$ particles were occasionally detected in the samples. Similar particles were observed by Li and Shao (2009b) and Moffet et al. (2008) in Beijing and Mexico City, respectively. The particles were thought to be from industrial activities and waste incinerators. In our samples, we also found abundant Pb-rich (Fig. S1) and some complex metal particles (Fig. 4c), suggesting that nonferrous metal industries could be a particle source.

Crustal mineral particles, common in every sample, have irregular shapes. In this study, three major mineral particle types are defined by their elemental composition (Fig. $4 \mathrm{~d}$ and $\mathrm{S} 1$ ), including Ca-rich (calcite and dolomite, particle a), Si$\mathrm{Al}$ (clay and feldspar, particle b), and Si-rich (quartz, particle c). Shi et al. (2005) indicated that those mineral types were the major crustal minerals in Asian dust storms over northern China. Particle a in Fig. 4d shows a visible coating on the surface of $\mathrm{Ca}$-rich particles. Similar coatings found by $\mathrm{Li}$ and Shao (2009a) and Tobo et al., (2010) in the polluted $\mathrm{NCP}$ were considered to be $\mathrm{Ca}\left(\mathrm{NO}_{3}\right)_{2}$, formed by the heterogeneous reaction of calcite (or dolomite) with $\mathrm{NO}_{2}$ or $\mathrm{HNO}_{3}$.

$\mathrm{Ca}-\mathrm{S} / \mathrm{N}$ particles contain $\mathrm{N}, \mathrm{O}, \mathrm{Ca}$, and $\mathrm{S}$ with minor $\mathrm{K}$. Each of the particles is an aggregate of two or more $\mathrm{CaSO}_{4}$ particles with well-defined shapes (Fig. 4e, particle a), and some of them also are internally mixed with $\mathrm{Ca}\left(\mathrm{NO}_{3}\right)_{2}$ (Fig. 4e, particle b). A small number of $\mathrm{Ca}-\mathrm{S} / \mathrm{N}$ particles can be found in the samples. The $\mathrm{CaSO}_{4}$ particles were most likely formed through aqueous chemical reactions of calcite with $\mathrm{H}_{2} \mathrm{SO}_{4}$ (Guo et al., 2010).

$\mathrm{Na} / \mathrm{K}-\mathrm{S} / \mathrm{N}$ particles are minor inorganic aerosol constituents in this study. EDS spectra of these particles suggest that they could be of two kinds, (1) mixtures of $\mathrm{NaNO}_{3}$ and $\mathrm{Na}_{2} \mathrm{SO}_{4}$ (particle a) or (2) $\mathrm{Na}_{2} \mathrm{SO}_{4}$ and $\mathrm{K}_{2} \mathrm{SO}_{4}$ (particle b) (Fig. 4a). They were considered to be the products of heterogeneous chemical reactions of terrestrial halite $(\mathrm{NaCl})$ from soil with acidic $\mathrm{SO}_{2}$ and $\mathrm{HNO}_{3}$ gases (Laskin et al., 2002). In this case, based on air mass back trajectories shown in Fig. 3 and on their rounded shape, the particles were likely from aged terrestrial halite.

Different aerosol particle types with diameters from $100 \mathrm{~nm}$ to $4 \mu \mathrm{m}$ are summarized in Fig. 5. The measured particle sizes from TEM images are larger than the actual ambi-

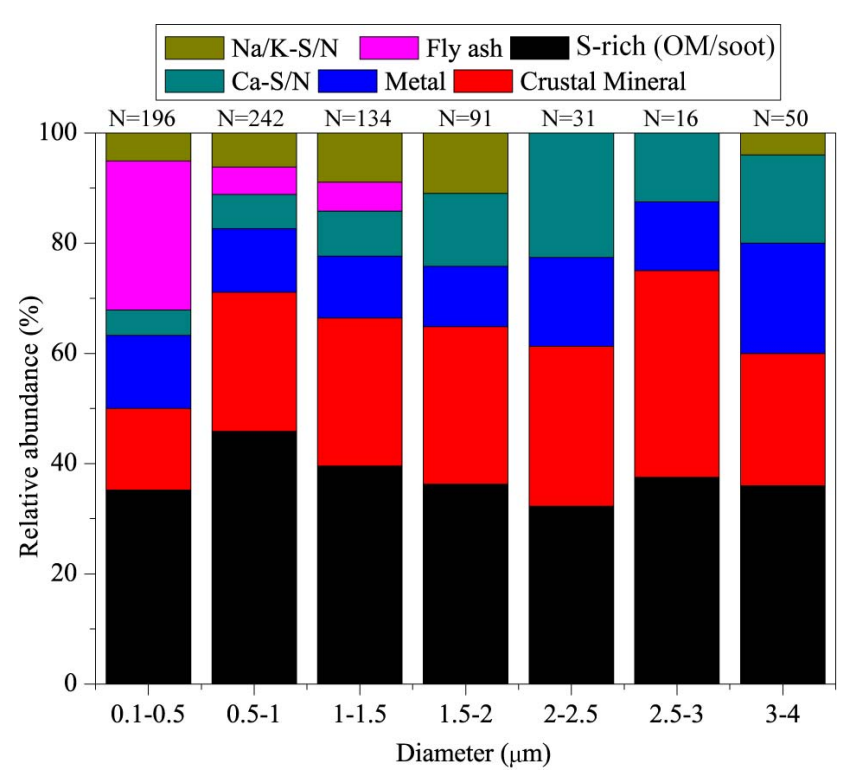

Fig. 5. Proportions of different aerosol particle types in different size ranges. A total of 717 aerosol particles were identified on bases of their different morphologies and compositions. The number of the analyzed aerosol particles in different size ranges is shown above each column. Fly ash, metal, and crustal mineral particles internally mixed with $\mathrm{S}$-rich particles were also included here.

ent sizes because the thickness of secondary particles on the carbon film decreases as particle collection proceeds (Posfai et al., 1998). The number fraction of crustal mineral particles displays no increase from fine to coarse modes, a pattern which has been described in the brown haze of Beijing by $\mathrm{Li}$ and Shao (2009b). Some crustal mineral particles were internally mixed with sulfates and $\mathrm{Ca}\left(\mathrm{NO}_{3}\right)_{2}$, like the particles shown in Fig. 4d. Abundant crustal mineral particles in the PBL from phase-I and -II were expected to originate from anthropogenic activities such as construction, road dust, and cement manufacturing. On the other hand, abundant spherical fly ash and metal particles were internally mixed with sulfates, suggesting that the coal-fired power plants and steel plants in the NCP were responsible for the pollutants in the PBL. It is important to note that the coarser particles have more complex mixing characteristics according to the TEM observations. In other words, the sulfate/OM particles with larger sizes were internally mixed with more refractory particles (e.g., soot, fly ash, metal, mineral particles).

\subsection{Individual aerosol particles in three phases}

Based on TEM analysis of individual aerosol particles, we estimate the number fractions of different particle types in the three phases (Fig. 6). Aerosol particles in phase-I and -II were mainly S-rich particles (47-49\%), followed by crustal mineral particles (13-20\%), fly ash (11-14\%), Ca-S/N (10$12 \%), \mathrm{Na} / \mathrm{K}-\mathrm{S} / \mathrm{N}(5-7 \%)$, and metal particles (4-6\%). In 
(a) Case 1

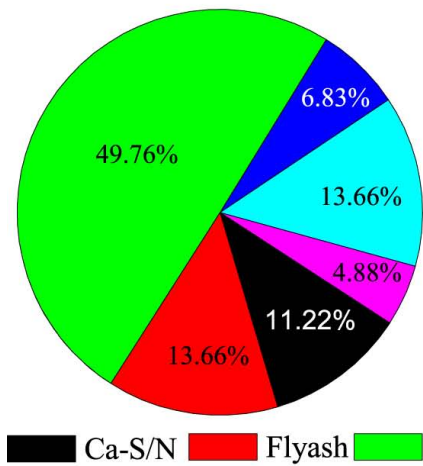

(b) Case 2

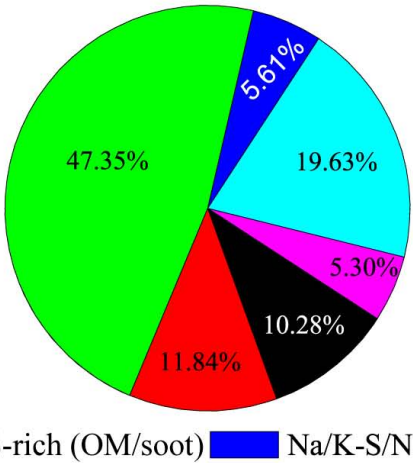

(c) Case 3

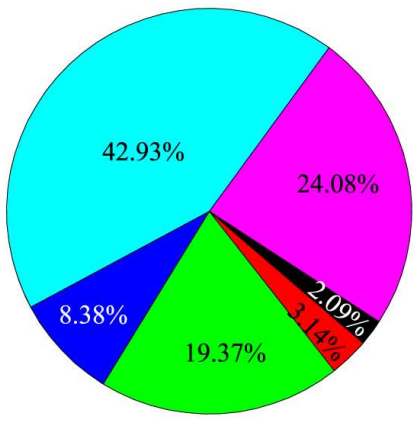

Crustal mineral

Fig. 6. Number fractions of particle types measured by the TEM/EDS. (a) 205 individual aerosol particles were analyzed in phase-I; $38 \%$ of S-rich particles were internally mixed with soot. (b) 321 individual aerosol particles were analyzed in phase-II; $83 \%$ of S-rich particles were internally mixed with soot. (c) 191 individual aerosol particles were analyzed in phase-III; $72 \%$ of S-rich particles were internally mixed with soot.

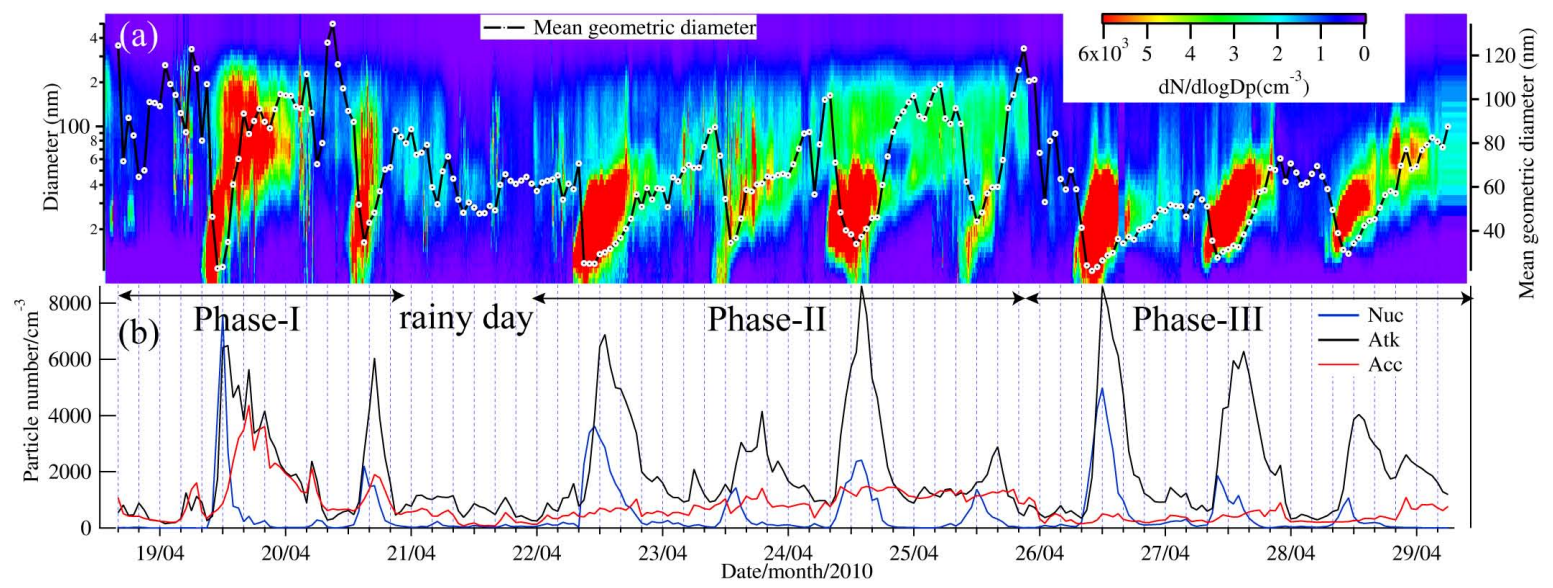

Fig. 7. (a) Diurnal evolution of particle number and size distribution at the summit of Mt. Tai during 19-28 April, 2010. The black line represents the changes of geometric mean diameter of aerosol particles following the time. (b) Particle number concentrations of nucleation mode (Nuc, diameter 10-20 nm), Aitken mode (Atk, diameter 20-100 nm), and accumulation mode (Acc, diameter 100-1000 nm).

phase-III, crustal mineral particles (43\%) were a dominant constituent, and the rest consisted of metal (24\%), S-rich (19\%), Na/K-S/N (9\%), fly ash (3\%), and Ca-S/N (2\%).

Comparisons of number fractions of different particle types in the three phases indicate that easterly and southerly air masses in phase-I and -II brought anthropogenic pollutants to the summit of Mt. Tai. Moreover, the high mass concentrations of sulfates and nitrates in $\mathrm{PM}_{2.5}$ (Table S1) suggest that secondary aerosol particles from gaseous $\mathrm{SO}_{2}$ and $\mathrm{NO}_{\mathrm{x}}$ dominated in these elevated layers. Moreover, the soluble ions accounted for about $60 \%$ of the $\mathrm{PM}_{2.5}$ mass in phase-I and -II, with sulfates being the major aerosol component (Table S1). These measured values are consistent with the $62 \%$ reported for the summer on Mt. Tai by Zhou et al. (2009). Zhou et al. (2009) also showed that both the $\mathrm{PM}_{2.5}$ and water-soluble ionic concentrations on Mt. Tai are higher than on other mountaintops of similar altitude elsewhere in the world.

It was noticed that abundant $\mathrm{Pb}$-rich particles were only detected in the two samples collected immediately after the cold front about 18:00 LT on 26 April (Fig. S1). TEM analysis shows that these particles were predominantly externally mixed. These coarse crustal mineral and metal particles probably originated from soil and/or from some nonferrous metal industries northwest of Mt. Tai. In phase-III, the soluble ions only accounted for $35 \%$ of the $\mathrm{PM}_{2.5}$ mass (Table S1). TEM observations show that abundant crustal mineral particles (43\% in Fig. 6c) remained suspended in the atmosphere after the dust storm, although visibility was not significantly affected. Therefore, abundant fine mineral particles were transported by northwesterly air masses into the free troposphere on 27 and 28 April and they remained suspended 


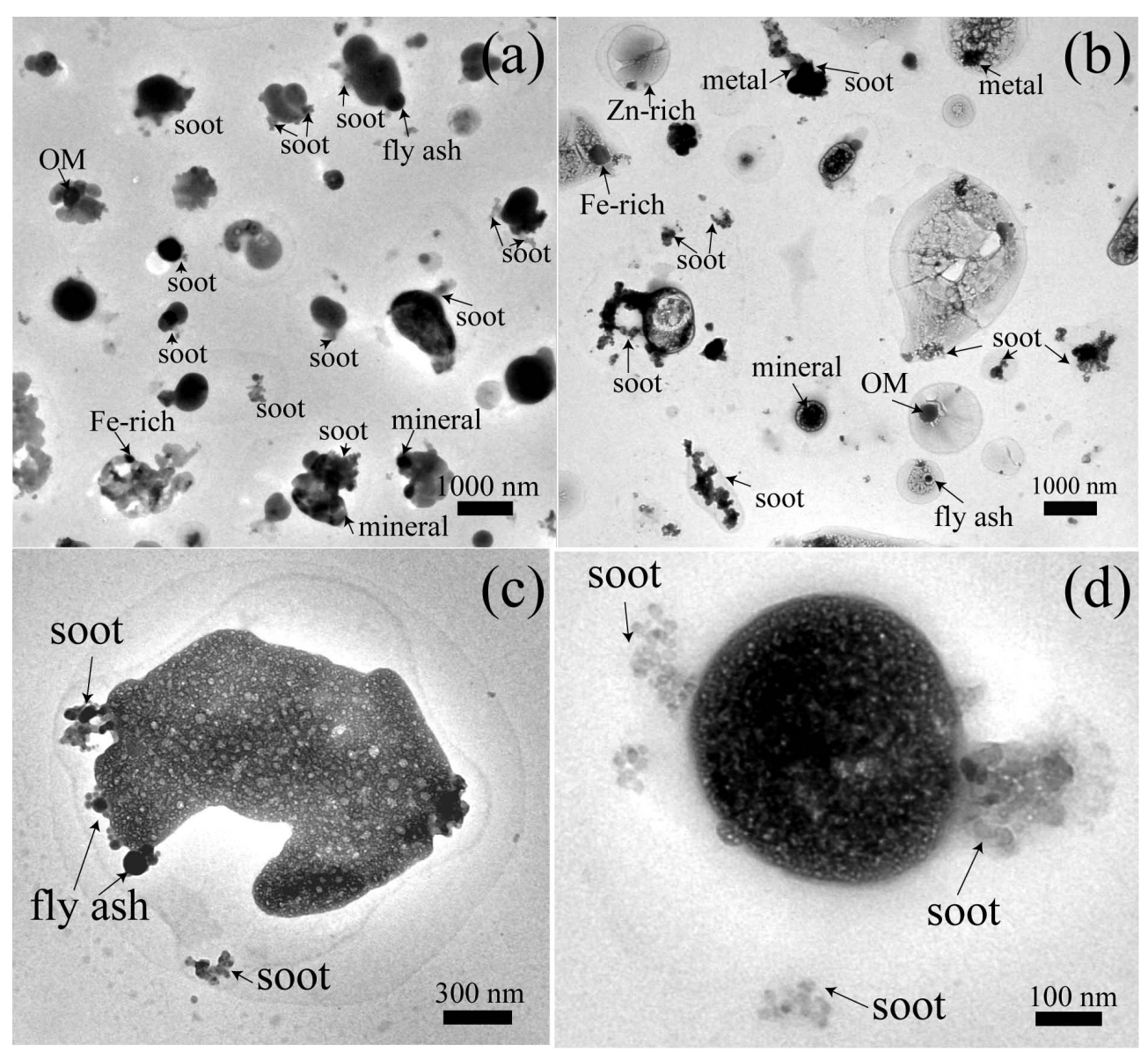

Fig. 8. TEM images of individual aerosol particles. Organic coatings of sulfate particles are not marked. (a) A low-magnification TEM image shows the aged S-rich particles mixed with mineral, soot, metal, and fly ash particles (20 April 15:00) (b) A low-magnification TEM image (24 April 11:00) (c) A high-magnification TEM image shows an aged S-rich particle mixed with the tiny fly ash and soot particles (23 April 16:00). (d) A high-magnification TEM image shows an aged S-rich particle mixed with soot particles (19 April 17:00).

one to two days after the strong dust storm of 26 April (Fig. 3 and $6 c)$.

\subsection{New particle formation and growth events}

Except on the rainy day of 21 April, NPF followed by particle growth was observed under the haze conditions in phaseI and phase-II (Fig. 7). Figure 7b further shows that diurnal particle number exhibits a significant increase in the nucleation and Aitken mode and a weak change in the accumulation mode. The peaks of particle number in the nucleation and Aitken modes in Fig. 7b represent the NPF and particle growth periods on each day, respectively. Particle growth lasted as long as $6 \mathrm{~h}(12: 00 \mathrm{LT}$ to 18:00 LT), and then resulted in a significant increase of particle geometric mean diameter from $10-22 \mathrm{~nm}$ in the morning to $56-96 \mathrm{~nm}$ in the evening (Fig. 7a). However, Wu et al. (2007) found that NPF events were uncommon in the polluted area of northern China because of rather high concentrations of the pre-existing particles near the ground level. These results provide insights into regional NPF events, which can frequently occur at upper levels of the regional haze layers rather than near the surface layer in the NCP. Moreover, air mass back trajectories in Fig. 3 show that most of particles in the nucleation mode were possibly formed 1000-2000 m above ground on a regional scale. Compared with the atmospheric environment of the surface layer, it is likely that the intense solar radiation and less polluted and cool conditions in elevated layers favor particle nucleation. On the other hand, weak NPF and robust particle growth events did occur in phase-III (Fig. 7).

\section{Discussion}

TEM and IC analyses of aerosol particles show that sulfates with organic coatings in the fine mode were a dominant aerosol type in phase-I and -II (Figs. 4c and 5). This result suggests that certain concentrations of sulfuric acid and secondary organic compounds on a regional scale should be important factors for particle nucleation. On Mt. Tai, Fu 
et al. (2010) and Wang et al. (2009) found that volatile organic compounds (VOCs) from anthropogenic activities on the plain below significantly contributed to the formation of water-soluble organics in the fine mode. These VOCs are generally involved in particle nucleation and their subsequent growth has been demonstrated in field experiments in plains and on mountaintops (Boulon et al., 2010; Jeong et al., 2010; Kulmala et al., 2005; Paasonen et al., 2010; Zhang et al., 2007).

Robust particle growth suggests that anthropogenic pollutants in the elevated air masses maintained new particle growth for more than $4 \mathrm{~h}$ (Fig. 7a). Apart from sulfuric acid and organic compounds, ammonium can significantly participate in new particle growth (Zhang et al., 2004). The increasing RH after 16:00 on Mt. Tai (Fig. 2) might also influence particle size because of hygroscopic growth. However, whether fine pre-existing particles influence the initiation of particle nucleation and growth processes in polluted industrial areas has not been determined in these aforementioned studies. TEM analysis of individual aerosol particles collected in morning and afternoon revealed that many S-rich particles were generally mixed with one or more refractory particles (e.g., soot, fly ash, and metal particles) in phase-I and -II (Fig. 8). Although it cannot be known whether these aged particles were formed during the NPF processes or at ground level, these particles in the fine mode were prevalent in the air masses. Therefore, we need to consider that particle nucleation and growth in the upper levels of the haze layers were likely related to those fine anthropogenic particles (Fig. 8c-d). TEM observations estimated that soot, fly ash, or metal particles typically enlarged sulfate particles diameters by more than $10 \mathrm{~nm}$. These mixing characteristics indicate direct evidence that the fine aerosol particles from steel industries, coal-fired power plants, and vehicular emissions might have contributed to their subsequent growth through condensation and coagulation in the upper atmosphere over the NCP. Moreover, the TEM observations suggest that fine refractory particles from anthropogenic sources were plentiful in the haze layers - numerous enough to suppress the initiation of particle nucleation via condensation and to subsequently weaken the NPF. Further attention to this issue should be paid in the North China plain with its diverse and numerous large emission sources such as coal-fired power plants, steel industries, populated cities, and deserts.

On clear days NPF was very weak, with the growth occurring from noon to 18:00 LT (Fig. 7). In contrast, Wu et al. (2007) and Shen et al. (2011) observed NPF in clear and dust-free days on the ground in the NCP whenever winds were from the northwest. Such northwesterly air masses can either "sweep out" the anthropogenic pollutants that accumulate over the NCP or carry abundant dust particles into downwind areas. In this study, abundant alkaline mineral particles partly mixed with nitrates and sulfates (Fig. 4d) indicate that these mineral particles in the free troposphere supplied an important surface on which acidic gases (e.g., $\mathrm{SO}_{2}$ and
$\mathrm{NO}_{x}$ ) or liquids condensed. The heterogeneous reactions between calcite/dolomite and $\mathrm{SO}_{2} / \mathrm{NO}_{2}$ or their acids can result in an internally mixed particle, as shown in Fig. 4d, which has been already found in the atmosphere over the NCP and its downwind areas (Li and Shao, 2009a; Tobo et al., 2010). Compared with 47-49\% S-rich particles in phase-I and -II (Fig. 6a and b), phase-III was dominated by mineral particles, at $43 \%$ (Fig. 6c). The difference indicates that NPF processes in which sulfur acids or sulfates are formed by $\mathrm{SO}_{2}$ reactions were likely reduced in phase-III. Although we cannot effectively account for the number of coarse dust particles through the WPS, TEM observations show that abundant mineral particles with various sizes from the northwesterly air masses contained some sulfur, as shown in Fig. 4d. We conclude, therefore, that the weak NPF can be attributed to the low concentrations of $\mathrm{SO}_{2}$ on clear days over the $\mathrm{NCP}$ because of the scavenging by abundant crustal mineral particles.

Regional particle nucleation and growth events on Mt. Tai usually occurred during late morning (10:00-12:00 LT) and throughout the afternoon (12:00-18:00 LT) (Fig. 7a). Following cloud formation after 18:00 LT, continuous particle growth process was normally interrupted because more than half of the aerosol particles were scavenged by clouds (Li et al., 2011). A significant decrease in aerosol concentration after 18:00 LT was due to the aerosol particles acting as CCN. Lower number concentrations of aerosols also occurred during nighttime (19:00-08:00 LT), which was 2-3 times lower than that during daytime (08:00-18:00 LT) (Fig. 7).

During phase-I and -II, various anthropogenic pollutants frequently appeared at the summit of Mt. Tai. S-rich particles as the major particle type were internally mixed with $\mathrm{OM}$, soot, fly ash, or metal particles. Sulfate formation has the potential to change the hygroscopic properties of hydrophobic soot, fly ash, and metal particles (Zuberi et al., 2005), enhancing their CCN ability (Wang et al., 2010). The tiny soot particles embedded in sulfates dominated the S-rich particles with $38 \%$ in phase-I, $83 \%$ in phase-II, and $72 \%$ in phase-III (Fig. 6). As a result, the polluted air masses from the south and southwest may lead to the amplification of radiation absorption by the particles because the surface sulfate coating could act as lenses to focus light on soot particles (Adachi et al., 2010; Bond et al., 2006). On the other hand, light scattering of individual particles can increase due to particle growth (Lewis et al., 2009). Therefore, the abundant sulfate particles internally mixed with tiny soot particles at upper levels over the polluted NCP are expected to complicate the radiation transfer and heat balance processes, rather than simply heating or cooling the upper atmosphere. Particle composition and elevation may extend their lifetimes and cause widespread dimming on the ground (Ramanathan et al., 2005). When a mass of low-level clouds formed after sunset, the new particles in the upper levels of hazy layers grew up to $\sim 100 \mathrm{~nm}$ or larger, the right size for acting as CCN (Dusek et al., 2006). Therefore, the NPF and 
the subsequent particle growth were closely related to the fog/cloud formation and precipitation on a regional scale.

\section{Conclusions}

On Mt. Tai, we found three regimes of pollutant sources: phase-I (19-21 April 2010), when prevailing winds were from the northeast to east, phase-II (22-25 April), when they were from the southwest to south, and phase-III (2628 April), when they were from the northwest. Visible haze layers were observed in phase-I (except for one rainy day) and in phase-II, but no haze (except one short dust storm on 26 April) was observed after 26 April. On the basis of the composition and morphology, we classified particles into six groups: S-rich (OM/soot), fly ash, metal, crustal mineral, $\mathrm{Ca}-\mathrm{S} / \mathrm{N}$, and $\mathrm{Na} / \mathrm{K}-\mathrm{S} / \mathrm{N}$. Aerosol particles in phase-I and -II were mainly S-rich particles (47-49\%), followed by crustal mineral particles (13-20\%), fly ash (11-14\%), Ca$\mathrm{S} / \mathrm{N}(10-12 \%), \mathrm{Na} / \mathrm{K}-\mathrm{S} / \mathrm{N}(5-7 \%)$, and metal particles (4$6 \%)$. In phase-III, crustal mineral particles $(43 \%)$ were the dominant constituent, and the rest consisted of metal (24\%), S-rich (19\%), Na/K-S/N (9\%), fly ash (3\%), and Ca-S/N $(2 \%)$. Comparisons of number fractions of different particle types in the three phases indicate that easterly, southerly, and southwesterly air masses in phase-I and -II brought anthropogenic pollutants to the summit of Mt. Tai, while northwesterly air masses in phase-III brought dust particles in the free troposphere.

Regional nucleation and growth events were restricted to the daytime: 10:00-12:00 LT and 12:00-18:00 LT. This daytime particle growth resulted in an increase of particle geometric mean diameter from $10-22 \mathrm{~nm}$ in the morning to $56-$ $96 \mathrm{~nm}$ in the evening. Compared with the surface layer, the intense solar radiation and the less polluted, cooler air in the PBL enhanced particle nucleation and growth. Acidic gases and VOCs emitted from anthropogenic sources were readily dispersed to upper levels and formed significant concentrations of secondary aerosol particles.

TEM observations also show that the internally mixed preexisting particles (e.g., soot, metal, and fly ash) could weaken NPF and enhance growth processes in haze layers. Moreover, high numbers of crustal mineral particles transported in northwesterly air masses in the free troposphere may supply sufficient surface areas for the condensation of acidic gases (e.g., $\mathrm{SO}_{2}$ and $\mathrm{NO}_{\mathrm{x}}$ ) and may disturb the NPF processes. Therefore, individual particle properties, when considered at the microscale, can reveal some phenomena during NPF and subsequent particle growth at the macroscale.

\section{Supplement related to this article is available online at: http://www.atmos-chem-phys.net/11/11733/2011/ acp-11-11733-2011-supplement.pdf.}

Acknowledgements. We appreciate Peter Hyde's comments and proofreading. Financial supports were provided by National Basic Research Program of China (2011CB403401), National Natural Science Foundation of China (41105088, 41175109), and Natural Science Foundation of Shandong Province (ZR2011DQ001), and State Key of Laboratory of Atmospheric Boundary Physics and Atmospheric Chemistry (LAPC-KF-2010-07).

Edited by: D. Knopf

\section{References}

Adachi, K. and Buseck, P. R.: Internally mixed soot, sulfates, and organic matter in aerosol particles from Mexico City, Atmos. Chem. Phys., 8, 6469-6481, doi:10.5194/acp-8-6769-2008, 2008.

Adachi, K., Chung, S. H., and Buseck, P. R.: Shapes of soot aerosol particles and implications for their effects on climate, J. Geophys. Res., 115, D15206, doi:10.1029/2009JD012868, 2010.

Andreae, M. O. and Rosenfeld, D.: Aerosol-cloud-precipitation interactions. Part 1. The nature and sources of cloud-active aerosols, Earth-Sci. Rev., 89, 13-41, 2008.

Bond, T. C., Habib, G., and Bergstrom, R. W.: Limitations in the enhancement of visible light absorption due to mixing state, J. Geophys. Res., 111, D20211, doi:10.1029/2006JD007315, 2006.

Boulon, J., Sellegri, K., Venzac, H., Picard, D., Weingartner, E., Wehrle, G., Collaud Coen, M., Butikofer, R., Fluckiger, E., Baltensperger, U., and Laj, P.: New particle formation and ultrafine charged aerosol climatology at a high altitude site in the Alps (Jungfraujoch, $3580 \mathrm{~m}$ a.s.1., Switzerland), Atmos. Chem. Phys., 10, 9333-9349, doi:10.5194/acp-10-9333-2010, 2010.

Chen, Y., Shah, N., Huggins, F. E., and Huffman, G. P.: Microanalysis of ambient particles from Lexington, KY, by electron microscopy, Atmos. Environ., 40, 651-663, 2006.

Cziczo, D. J., Stetzer, O., Worringen, A., Ebert, M., Weinbruch, S., Kamphus, M., Gallavardin, S. J., Curtius, J., Borrmann, S., Froyd, K. D., Mertes, S., Mohler, O., and Lohmann, U.: Inadvertent climate modification due to anthropogenic lead, Nature Geosci., 2, 333-336, 2009.

Dusek, U., Frank, G. P., Hildebrandt, L., Curtius, J., Schneider, J., Walter, S., Chand, D., Drewnick, F., Hings, S., Jung, D., Borrmann, S., and Andreae, M. O.: Size matters more than chemistry for cloud-nucleating ability of aerosol particles, Science, 312, 1375-1378, 2006.

Ebert, M., Weinbruch, S., Hoffmann, P., and Ortner, H. M.: The chemical composition and complex refractive index of rural and urban influenced aerosols determined by individual particle analysis, Atmos. Environ. 38, 6531-6545, 2004.

Fang, M., Chan, C. K., and Yao, X.: Managing air quality in a rapidly developing nation: China, Atmos. Environ., 43, 79-86, 2009.

Fu, P., Kawamura, K., Kanaya, Y., and Wang, Z.: Contributions of biogenic volatile organic compounds to the formation of secondary organic aerosols over Mt. Tai, Central East China, Atmos. Environ., 44, 4817-4826, 2010.

Fuzzi, S., Andreae, M. O., Huebert, B. J., Kulmala, M., Bond, T. C., Boy, M., Doherty, S. J., Guenther, A., Kanakidou, M., Kawamura, K., Kerminen, V. M., Lohmann, U., Russell, L. M., and Pöschl, U.: Critical assessment of the current state of scien- 
tific knowledge, terminology, and research needs concerning the role of organic aerosols in the atmosphere, climate, and global change, Atmos. Chem. Phys., 6, 2017-2038, doi:10.5194/acp-62017-2006, 2006.

Geng, H., Kang, S., Jung, H.-J., Choel, M., Kim, H., and Ro, C.-U.: Characterization of individual submicrometer aerosol particles collected in Incheon, Korea, by quantitative transmission electron microscopy energy-dispersive X-ray spectrometry, J. Geophys. Res., 115, D15306, doi:10.1029/2009JD013486, 2010.

Giere, R., Blackford, M., and Smith, K.: TEM study of PM 2.5 emitted from coal and tire combustion in a thermal power station, Environ. Sci. Tech., 40, 6235-6240, 2006.

Guo, Z., Li, Z., Farquhar, J., Kaufman, A. J., Wu, N., Li, C., Dickerson, R. R., and Wang, P.: Identification of sources and formation processes of atmospheric sulfate by sulfur isotope and scanning electron microscope measurements, J. Geophys. Res., 115, D00K07, doi:10.1029/2009JD012893, 2010.

He, K., Huo, H., and Zhang, Q.: Urban air pollution in China: Current Status, Characteristics, and Progress, Ann. Rev. Energ. Environ., 27, 397-431, 2002.

Hudson, J.G.: Variability of the relationship between particle size and cloud-nucleating ability, Geophy. Res. Lett., 34 (L0880), doi:10.1029/2006GL028850, 2007.

Jacob, D. J., Crawford, J. H., Kleb, M. M., Connors, V. S., Bendura, R. J., Raper, J. L., Sachse, G. W., Gille, J. C., Emmons, L., and Heald, C. L.: Transport and Chemical Evolution over the Pacific (TRACE-P) aircraft mission: Design, execution, and first results, J. Geophys. Res., 108, 9000, doi:10.1029/2002JD003276, 2003.

Jaffe, D., Anderson, T., Covert, D., Kotchenruther, R., Trost, B., Danielson, J., Simpson, W., Berntsen, T., Karlsdottir, S., Blake, D., Harris, J., Carmichael, G., and Uno, I.: Transport of Asian air pollution to North America, Geophys. Res. Lett., 26, 711714, 1999.

Jeong, C. H., Evans, G. J., McGuire, M. L., Chang, R. Y. W., Abbatt, J. P. D., Zeromskiene, K., Mozurkewich, M., Li, S. M., and Leaitch, W. R.: Particle formation and growth at five rural and urban sites, Atmos. Chem. Phys., 10, 7979-7995, doi:10.5194/acp10-7979-2010, 2010.

Kahn, R., Anderson, J., Anderson, T. L., Bates, T., Brechtel, F., Carrico, C. M., Clarke, A., Doherty, S. J., Dutton, E., Flagan, R., Frouin, R., Fukushima, H., Holben, B., Howell, S., Huebert, B., Jefferson, A., Jonsson, H., Kalashnikova, O., Kim, J., Kim, S. W., Kus, P., Li, W. H., Livingston, J. M., McNaughton, C., Merrill, J., Mukai, S., Murayama, T., Nakajima, T., Quinn, P., Redemann, J., Rood, M., Russell, P., Sano, I., Schmid, B., Seinfeld, J., Sugimoto, N., Wang, J., Welton, E. J., Won, J. G., and Yoon, S. C.: Environmental snapshots from ACE-Asia, J. Geophys. Res., 109, D19S14, doi:10.1029/2003JD004339, 2004.

Kulmala, M., Petaja, T., Monkkonen, P., Koponen, I. K., Dal Maso, M., Aalto, P. P., Lehtinen, K. E. J., and Kerminen, V. M.: On the growth of nucleation mode particles: source rates of condensable vapor in polluted and clean environments, Atmos. Chem. Phys., 5, 409-416, doi:10.5194/acp-5-409-2005, 2005.

Laskin, A., Iedema, M.J., and Cowin, J.P.: Quantitative TimeResolved Monitoring of Nitrate Formation in Sea Salt Particles Using a CCSEM/EDX Single Particle Analysis, Environ. Sci. Technol., 36, 4948-4955, 2002.

Lee, S. H., Murphy, D. M., Thomson, D. S., and Middlebrook, A. M.: Chemical components of single particles measured with
Particle Analysis by Laser Mass Spectrometry (PALMS) during the Atlanta SuperSite Project: Focus on organic/sulfate, lead, soot, and mineral particles, J. Geophys. Res., 107, 4003, doi:10.1029/2000JD000011, 2002.

Li, W. J. and Shao, L. Y.: Observation of nitrate coatings on atmospheric mineral dust particles, Atmos. Chem. Phys., 9, 18631871, doi:10.5194/acp-9-1863-2009, 2009a.

Li, W. J. and Shao, L. Y.: Transmission electron microscopy study of aerosol particles from the brown hazes in northern China, J. Geophys. Res., 114, D09302, doi:10.1029/2008JD011285, 2009b.

Li, W. J., Shao, L. Y., and Buseck, P. R.: Haze types in Beijing and the influence of agricultural biomass burning, Atmos. Chem. Phys., 10, 8119-8130, doi:10.5194/acp-10-8119-2010, 2010.

Li, W. J., Zhou, S. Z., Yuan, Q., Li, P. R., Sun, G. D., and Wang, W. X.: Cloud residues and interstitial aerosols from nonprecipitating clouds over an industrial and urban area in northern China, Atmos. Environ., 45, 2488-2495, 2011.

Lohmann, U. and Feichter, J.: Global indirect aerosol effects: a review, Atmos. Chem. Phys., 5, 715-737, doi:10.5194/acp-5-7152005, 2005.

Lu, Z., Streets, D. G., Zhang, Q., Wang, S., Carmichael, G. R., Cheng, Y. F., Wei, C., Chin, M., Diehl, T., and Tan, Q.: Sulfur dioxide emissions in China and sulfur trends in East Asia since 2000, Atmos. Chem. Phys., 10, 6311-6331, doi:10.5194/acp-106311-2010, 2010.

Marple, V. A., Rubow, K. L., and Olson, B. A.: Inertial, Gravitational, Centrifugal, and Thermal Collection Techniques., in: Aerosol Measurement, edited by: Willike, K., Baron, P. A., 206233, Van Nostrand Reinhold, New York, USA, 1993.

Matsuki, A., Quennehen, B., Schwarzenboeck, A., Crumeyrolle, S., Venzac, H., Laj, P., and Gomes, L.: Temporal and vertical variations of aerosol physical and chemical properties over West Africa: AMMA aircraft campaign in summer 2006, Atmos. Chem. Phys., 10, 8437-8451, doi:10.5194/acp-10-84372010, 2010.

Merikanto, J., Spracklen, D. V., Mann, G. W., Pickering, S. J., and Carslaw, K. S.: Impact of nucleation on global CCN, Atmos. Chem. Phys., 9, 8601-8616, doi:10.5194/acp-9-8601-2009, 2009.

Moffet, R. C., Desyaterik, Y., Hopkins, R. J., Tivanski, A. V., Gilles, M. K., Wang, Y., Shutthanandan, V., Molina, L. T., Abraham, R. G., Johnson, K. S., Mugica, V., Molina, M. J., Laskin, A., and Prather, K. A.: Characterization of aerosols containing $\mathrm{Zn}, \mathrm{Pb}$, and $\mathrm{Cl}$ from an industrial region of Mexico City, Environ. Sci. Technol., 42, 7091-7097, 2008.

Moffet, R. C., Henn, T. R., Tivanski, A. V., Hopkins, R. J., Desyaterik, Y., Kilcoyne, A. L. D., Tyliszczak, T., Fast, J., Barnard, J., Shutthanandan, V., Cliff, S. S., Perry, K. D., Laskin, A., and Gilles, M. K.: Microscopic characterization of carbonaceous aerosol particle aging in the outflow from Mexico City, Atmos. Chem. Phys., 10, 961-976, doi:10.5194/acp-10-961-2010, 2010.

Murphy, D. M., Cziczo, D. J., Froyd, K. D., Hudson, P. K., Matthew, B. M., Middlebrook, A. M., Peltier, R. E., Sullivan, A., Thomson, D. S., and Weber, R.J.: Single-particle mass spectrometry of tropospheric aerosol particles, J. Geophys. Res., 111, D23S32, doi:10.1029/2006JD007340, 2006.

Niemi, J.V., Saarikoski, S., Tervahattu, H., Makela, T., Hillamo, R., Vehkamaki, H., Sogacheva, L., and Kulmala, M.: Changes in 
background aerosol composition in Finland during polluted and clean periods studied by TEM/EDX individual particle analysis, Atmos. Chem. Phys., 6, 5049-5066, doi:10.5194/acp-6-50492006, 2006.

Paasonen, P., Nieminen, T., Asmi, E., Manninen, H. E., Petaja, T., Plass-Dulmer, C., Flentje, H., Birmili, W., Wiedensohler, A., Horrak, U., Metzger, A., Hamed, A., Laaksonen, A., Facchini, M. C., Kerminen, V. M., and Kulmala, M.: On the roles of sulphuric acid and low-volatility organic vapours in the initial steps of atmospheric new particle formation, Atmos. Chem. Phys., 10, 11223-11242, doi:10.5194/acp-10-11223-2010, 2010.

Knopf, D. A., Wang, B., Laskin, A., Moffet, R. C., and Gilles, M. K.: Heterogeneous nucleation of ice on anthropogenic organic particles collected in Mexico City, Geophys. Res. Lett., 37, L11803, doi:10.1029/2010GL043362, 2010.

Posfai, M., Xu, H. F., Anderson, J. R., and Buseck, P. R.: Wet and dry sizes of atmospheric aerosol particles: An AFM-TEM study, Geophys. Res. Lett., 25, 1907-1910, 1998.

Posfai, M., Simonics, R., Li, J., Hobbs, P. V., and Buseck, P. R.: Individual aerosol particles from biomass burning in southern Africa: 1. Compositions and size distributions of carbonaceous particles, J. Geophys. Res., 108, 8483, doi:10.1029/2002JD002291, 2003.

Pratt, K. A. and Prather, K. A.: Aircraft measurements of vertical profiles of aerosol mixing states, J. Geophys. Res., 115, D11305, doi:10.1029/2009JD013150, 2010.

Pratt, K. A., Twohy, C. H., Murphy, S. M., Moffet, R. C., Heymsfield, A. J., Gaston, C. J., DeMott, P. J., Field, P. R., Henn, T. R., Rogers, D. C., Gilles, M. K., Seinfeld, J. H., and Prather, K. A.: Observation of playa salts as nuclei in orographic wave clouds, J. Geophys. Res., 115, D15301, doi:10.1029/2009JD013606, 2010.

Ramanathan, V., Chung, C., Kim, D., Bettge, T., Buja, L., Kiehl, J. T., Washington, W. M., Fu, Q., Sikka, D. R., and Wild, M.: Atmospheric brown clouds: Impacts on South Asian climate and hydrological cycle, P. Natl. Acad. Sci. USA, 102, 5326-5333, 2005.

Ren, Y., Ding, A., Wang, T., Shen, X., Guo, J., Zhang, J., Wang, Y., $\mathrm{Xu}$, P., Wang, X., Gao, J., and Collett Jr., J. L.: Measurement of gas-phase total peroxides at the summit of Mount Tai in China, Atmos. Environ., 43, 1702-1711, 2009.

Rosenfeld, D.: Suppression of Rain and Snow by Urban and Industrial Air Pollution, Science, 287, 1793-1796, 2000.

Shen, X. J., Sun, J. Y., Zhang, Y. M., Wehner, B., Nowak, A., Tuch, T., Zhang, X. C., Wang, T. T., Zhou, H. G., Zhang, X. L., Dong, F., Birmili, W., and Wiedensohler, A.: First longterm study of particle number size distributions and new particle formation events of regional aerosol in the North China Plain, Atmos. Chem. Phys., 11, 1565-1580, doi:10.5194/acp-11-15652011, 2011.

Shi, Z. B., Shao, L. Y., Jones, T. P., and Lu, S. L.: Microscopy and mineralogy of airborne particles collected during severe dust storm episodes in Beijing, China, J. Geophys. Res., 110, 13031303, 2005.

Tobo, Y., Zhang, D., Matsuki, A., and Iwasaka, Y.: Asian dust particles converted into aqueous droplets under remote marine atmospheric conditions, P. Natl. Acad. Sci. USA, 107, 17905-17910, 2010 .
Wang, G., Kawamura, K., Umemoto, N., Xie, M., Hu, S., and Wang, Z.: Water-soluble organic compounds in $\mathrm{PM}_{2.5}$ and sizesegregated aerosols over Mount Tai in North China Plain, J. Geophys. Res., 114, D19208, doi:10.1029/2008JD011390, 2009.

Wang, G., Li, J., Cheng, C., Hu, S., Xie, M., Gao, S., Zhou, B., Dai, W., Cao, J., and An, Z.: Observation of atmospheric aerosols at Mt. Hua and Mt. Tai in central and east China during spring 2009 - Part 1: EC, OC and inorganic ions, Atmos. Chem. Phys., 11, 4221-4235, doi:10.5194/acp-11-4221-2011, 2011.

Wang, J., Cubison, M. J., Aiken, A. C., Jimenez, J. L., and Collins, D. R.: The importance of aerosol mixing state and size-resolved composition on $\mathrm{CCN}$ concentration and the variation of the importance with atmospheric aging of aerosols, Atmos. Chem. Phys., 10, 7267-7283, doi:10.5194/acp-10-7267-2010, 2010.

Wild, M.: Global dimming and brightening: A review, J. Geophys. Res., 114, D00D16, doi:10.1029/2008JD011470, 2009.

Wu, Z., Hu, M., Liu, S., Wehner, B., Bauer, S., Maßing, A., Wiedensohler, A., Petaja, T., Dal Maso, M., and Kulmala, M.: New particle formation in Beijing, China: Statistical analysis of a 1-year data set, J. Geophys. Res., 112, D09209, doi:10.1029/2006JD007406, 2007.

Yamaji, K., Li, J., Uno, I., Kanaya, Y., Irie, H., Takigawa, M., Komazaki, Y., Pochanart, P., Liu, Y., Tanimoto, H., Ohara, T., Yan, X., Wang, Z., and Akimoto, H.: Impact of open crop residual burning on air quality over Central Eastern China during the Mount Tai Experiment 2006 (MTX2006), Atmos. Chem. Phys., 10, 7353-7368, doi:10.5194/acp-10-7353-2010, 2010.

Yang, F., Chen, H., Wang, X. N., Yang, X., Du, J. F., and Chen, J. M.: Single particle mass spectrometry of oxalic acid in ambient aerosols in Shanghai: Mixing state and formation mechanism, Atmos. Environ., 43, 3876-3882, 2009.

Zhang, D. Z., Shi, G. Y., Iwasaka, Y., and Hu, M.: Mixture of sulfate and nitrate in coastal atmospheric aerosols: individual particle studies in Qingdao (36 degrees 04' N, 120 degrees $21^{\prime} \mathrm{E}$ ), China, Atmos. Environ., 34, 2669-2679, 2000.

Zhang, Q., Stanier, C. O., Canagaratna, M. R., Jayne, J. T., Worsnop, D. R., Pandis, S. N., and Jimenez, J. L.: Insights into the Chemistry of New Particle Formation and Growth Events in Pittsburgh Based on Aerosol Mass Spectrometry, Environ. Sci. Technol., 38, 4797-4809, 2004.

Zhang, Q., Jimenez, J. L., Worsnop, D. R., and Canagaratna, M.: A Case Study of Urban Particle Acidity and Its Influence on Secondary Organic Aerosol, Environ. Sci. Technol., 41, 3213-3219, 2007.

Zhou, Y., Wang, T., Gao, X., Xue, L., Wang, X., Wang, Z., Gao, J., Zhang, Q., and Wang, W.: Continuous observations of watersoluble ions in $\mathrm{PM}_{2.5}$ at Mount Tai (1534 ma.s.1.) in centraleastern China, J. Atmos. Chem., 64, 107-127, 2009.

Zuberi, B., Johnson, K. S., Aleks, G. K., Molina, L. T., and Laskin, A.: Hydrophilic properties of aged soot, Geophys. Res. Lett., 32, doi:10.1029/2004GL021496, 2005. 